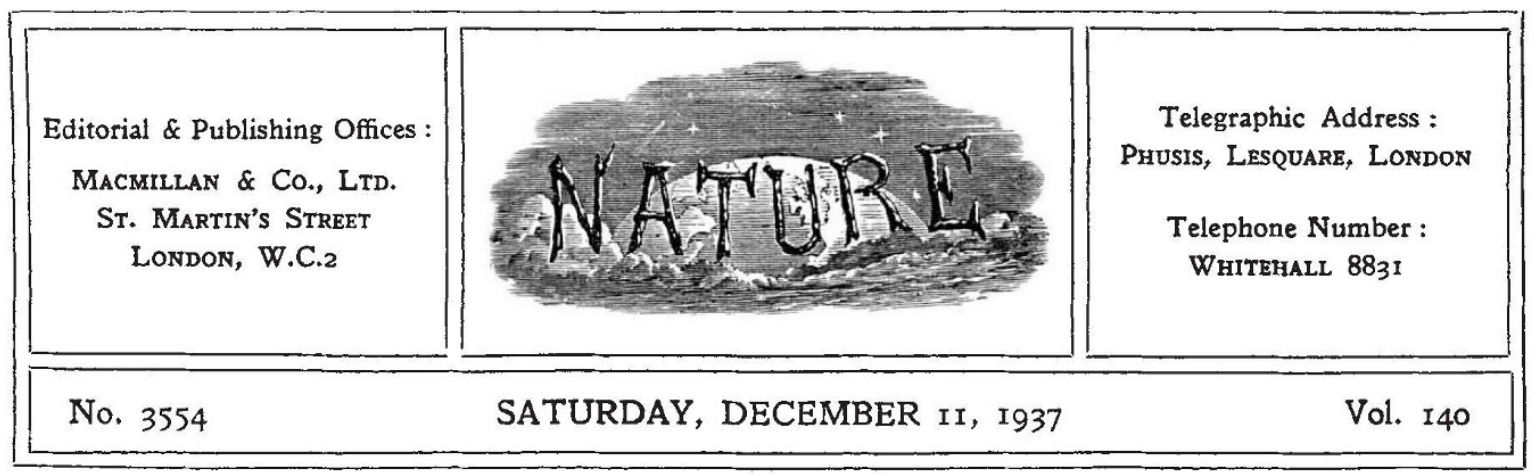

\title{
The University in Modern Life
}

$\mathrm{M}$ ORE than one discussion at the recent meeting of the British Association at Nottingham raised questions about the fundamental purpose and functions of the university in modern life which went far beyond the immediate practical problems under discussion. Some of these problemsfor example, the part of the university in education for citizenship - had been raised at the conference arranged by the Association for Education in Citizenship at Ashridge in July, while since the Nottingham meeting a lively attack on the inadequacy of the universities in regard to adult education has been delivered by Prof. L. Hogben in a paper "Education for an Age of Plenty" at the conference of the British Institute of Adult Education at Cambridge.

Prof. Hogben criticized the universities for not supplying directly the instruction which is immediately helpful in the task of salvaging democracy, and argued for more courses on public health, nutrition, the social services and the economies of everyday life. The university, of course, teaches the way to sources of such information, but for adult education a special technique is required and its curriculum is not necessarily that which should be followed by the university itself. As Mr. W. Spens pointed out at Ashridge, the university should be an introduction to later life and assist the initial understanding of problems rather than the formulation of conclusions or actual participation in political or economic contests.

The tribute paid to the Modern Greats course at Oxford in itself shows that even in education for democracy the universities have scarcely been so deficient as Prof. Hogben would appear to suggest. None the less, the many and diverse concrete suggestions which have been made as to the courses which a university should provide and the functions it should fill in a modern democratic society indicate that some fundamental reconsideration of their position is called for if their work is to be reorientated or planned to the better advantage of the community.

Most of the recent criticism of the universities has been concerned with their teaching functions, and a remarkable consensus of opinion has argued that this should be aimed more specifically at imparting the ideal of service and in training for citizenship and for leadership. In the discussion at Nottingham on the training of university graduates for the engineering industry, the importance of a broad training and one which stimulated participation in everyday affairs was repeatedly emphasized by different speakers. It was equally remarkable that not only was premature specialization in technical subjects recognized as undesirable, but also a definite suggestion was made, by Dr. A.P.M. Fleming, that the post-graduate instruction in the highly specialized and technical branches of engineering is a responsibility which the more progressive and larger industrial firms might well be expected to assume.

The significance of this suggestion lies, at least in part, in the fact that it was made by a representative of one of the most progressive firms in Great Britain, who himself has made an important contribution to technical training in that field. Obviously a proposal of this kind would involve very careful examination by all concerned before it could be adopted, but that it should be made at all indicates at least the existence of an atmosphere and a spirit of co-operation, in which the reorganization or reorientation of university courses to avoid overloading or excessive specialization and 
to encourage all-round training, creative and independent thinking and the development of personality becomes practicable. The plea for the provision of travelling scholarships for the further training of immediate graduates, to be maintained by industrialists, which Mr. R. H. Clayton has since made in his presidential address to the Manchester Literary and Philosophical Society, is another indication of the increasing readiness of the industrialist to co-operate.

We are here, of course, once more faced with the old question as to whether a university training should be primarily to give the knowledge required to qualify men and women for some special mode of gaining their livelihood, or to equip them as members of society and as human beings. It seems to be clear from almost all recent criticism of the training of scientific workers such as engineers and chemists, however, that under modern conditions even the first objective cannot be realized if the second is neglected. Alike in industrial, commercial and civic life a sense of values and of perspective is demanded of those who hold responsible positions in management or even in the direction of research itself.

The very complexity of the problems with which leadership is confronted in society to-day emphasizes the importance of the cultural elements in a university training, not only because of the large number of those who become leaders in the national life who must have been under its discipline, but also because of the importance of critical intelligence in the rank and file of democracy. Premature or excessive specialization in any branch of science, or indeed elsewhere, is now almost universally condemned, and the dictum that the only specialization at a university should be specialization in the fundamental principles of the science as subject studied commands general support. Dr. Fleming's suggestion, if taken up, might well assist both the universities and the technical colleges to avoid some of the dangers of the past and to concentrate on the fundamental task of turning out trained minds, able to absorb knowledge later in life when left to their own resources, and to take their proper part in the life of the nation.

However important the teaching function of the university may be, the training of men is only one of these functions. Equally important is the conservation of knowledge and ideas. Under present conditions, indeed, as the report of the University Grants Committee pointed out, an exceptional responsibility rests on British universities owing to the suppression in the universities of several European countries of all independent thought and critical discussion of the principles of government or of the meaning of life. Moreover, as Prof. M. Ginsberg pointed out in a thoughtful address in Section L (Educational Science) of the British Association on the functions of the universities in regard to the social sciences, there are important contributions which university study can offer to the clarification of the issues involved in many social and economic problems to-day, alike in regard to methods and assumptions made by the social sciences and in regard to the problem of values and moral issues. It was never more imperative that universities should be places where thought and disinterested inquiry are pursued on the highest level, and where the best minds of each generation are trained for intellectual achievement. The undoubted need for a re. orientation of our research effort so as to secure a more equable distribution between the social and biological and the physical sciences should not lead us to limit in any narrow spirit the funda. mental researches which the university may initiate in any branch of knowledge, or to seek to influence its strictly theoretical approach to such problems. Never, indeed, was it more important that the fundamental research pursued in the universities should be pursued in a spirit entirely free from bias, prejudice or preconceived ideas.

Significantly enough, in the very address in which he suggested that large-scale industry should assume some responsibility for specialized technical training in engineering, Dr. Fleming stressed the opportunities for co-operative research which exist in the engineering departments of the universities but which at present, largely for financial reasons, are far from being fully utilized. Especially is this true of research in borderline subjects which are often outside the scope of an industrial research laboratory. In research no less than in teaching, the possibilities of co-operation between the universities and industry have yet to be fully explored and developed, and co-operation in the way indicated by Dr. Fleming is likely to strengthen rather than impair the independence and resources of the university in regard to longrange and fundamental research on problems the practical bearing of which cannot yet be foreseen.

Under modern conditions, however, it has been suggested that these important functions, of 
teaching and training men, and research for the advancement of knowledge, are by no means the only functions which are required of a university. In our swiftly changing world, instructional studies ceases at about twenty-three years of age, and a man is very liable to lose intellectual energy by the time he is forty, and so fail to keep up with advancing knowledge. Sir Richard Livingstone, speaking in Section $\mathrm{L}$ at Nottingham, made a powerful plea that the universities should give attention to this problem of arranging systematic refresher or vacation courses at which those especially who occupy responsible positions in industrial, commercial or professional life, whether as managers or directors, should be able to refresh, re-equip and reorientate their minds and guard against the ever-present danger which the numbing effect of routine involves.

Here again, as Sir Richard Livingstone pointed out, is another field for co-operation between industry and the universities. If the special type of adult education required, enabling the student to place his special subject against the background of modern civilization, can only be supplied by the universities, the arrangement of such courses largely depends on the extent to which industry, commerce and the professions are willing to second promising officials for such systematic study. Moreover, it is probable that such a system offers the best means of giving the training in administration and management which is now generally recognized to be so important for those destined to fill the highest positions of management and control in industry. Apart from that, the contact thus established between the university and those with considerable practical experience of industry and the world of affairs can scarcely fail to have a very stimulating and helpful effect on the study of the social sciences at the university itself.
If, therefore, the universities are being called to reconsider their exact functions in our rapidly changing modern society, there is no less insistent call to industry and to society to consider their own relations with the university. The university cannot exercise the new functions unless the society in which it lives recognizes their value and is anxious that they should be performed. Not even in the training of men, whether for citizenship or for industry and the professions, can the university realize its highest ideals unless other sections of the community are prepared to co-operate with it, both by seeing that those entering a university have received an adequate general training, including some for citizenship upon which the university can base its own contribution, and by assisting in the provision of the detailed technical training required to equip those leaving the university for some particular vocation or branch of industry. The redistribution of research effort in relation to the fundamental needs of society and the planning of the reconditioning courses visualized by Sir Richard Livingstone demand as much thought from society as a whole as from the univer. sities. In considering, therefore, the criticism which has been levelled at the universities in recent months, it should not be forgotten, that the highest traditions of the university can only be realized in a community which is willing to co-operate generously with the university. Not even the material endowments of a university are of more vital importance than a true harmony of spirit in which the highest ideals of a university are cherished without as within its walls, and where the community no less than the university is concerned that the tradition of candid and intrepid thinking about the fundamental issues of life shall be handed on unimpaired from one generation to another.

\section{A Life of Lord Haldane}

Haldane, I856-I9I5:

the Life of Viscount Haldane of Cloan, K.T., O.M. By Major-General Sir Frederick Maurice. Pp. $\mathrm{xv}+394+8$ plates. (London: Faber and Faber, Ltd., 1937.) 18s. net.

VOLTAIRE'S saying, "We owe consideration to the living; to the dead we owe truth only", would have been accepted by Lord Haldane. His autobiography was published soon after his death; and a leading article in NATURE of April
20,1929 , discussed especially his services to science and education as set out therein. But Haldane, always an exceptional man, showed a diffidence in his last testament contrasting strangely with the somewhat arrogant conceit of his years of power. The personalities of the small group of politicians who held the destiny of the Empire in their hands during the pre-War years will always be of interest. Haldane's life should be a compulsory subject of study for politicians. 